\title{
EXPERIMENTAL RESEARCH ON THE VARIATION OF MECHANICAL PROPERTIES FOR AN ALUMINUM ALLOY SUBJECTED TO NATURAL AGEING
}

\author{
Marian-Iulian NEACȘU \\ "Dunarea de Jos" University of Galati, Romania \\ e-mail: uscaeni@yahoo.com
}

\begin{abstract}
Aluminum alloys, due to their properties, have a very wide field in which they find application in the industry. Out of these, the alloys in the Al-Zn system are used predominantly in the aeronautical and machine building industries.

In this paper, we investigated the variation in mechanical properties of the Al$\mathrm{Zn}$ alloy with a $\mathrm{Zn}$ content of $4.5 \%$, subjected to a natural ageing treatment with various ageing times.

After conducting the research, we found that the mechanical properties studied vary with the natural ageing time and not all of them fit into the prescriptions imposed by the Euronorm in force. The only property whose values fall entirely within the required limits is elongation at breaking.
\end{abstract}

KEYWORDS: aluminum alloys, quitting, natural aging, homogenization

\section{Introduction}

There is a close link between the development of the aeronautical industry and the evolution of the materials used. It is well-known that this state-of-theart field requires high performance materials with special physical-mechanical properties. Such materials require special elaboration and casting technologies as well as special further processing [1].

Aluminum alloys find their application in almost all branches of the contemporary industry, thus implicitly also in aeronautics due to special properties such as: high mechanical strength, low specific weight, chemical stability, good thermal conductivity, good to very good resistance to corrosion, etc. [2]. The close collaboration between aircraft manufacturers and metallurgical engineers has led to materials with special features and efficient equipment.

For a long time, the main materials used in aeronautics were high resistance duralumin (Al-Cu$\mathrm{Mg}$ ) alloys, but their range was reduced when special zicral-type aluminum alloys (Al-Zn-Mg-Cu) appeared [3].

In view of the choice of high strength aluminum alloys for the aeronautical industry, it must be taken into account that they must have high mechanical strength, satisfactory plasticity, corrosion resistance under load, and they also must have high fatigue strength and resistance to relatively high temperatures [4].

Due to their outstanding features, alloys in the $\mathrm{Al}-\mathrm{Zn}-\mathrm{Mg}-\mathrm{Cu}$ system are used primarily in the aerospace and machine-building industries.

$\mathrm{Al}-\mathrm{Zn}-\mathrm{Mg}-\mathrm{Cu}$ alloys are part of the deformable and hardening aluminum alloy category by applying thermal and (or) thermomechanical treatments [4].

The hardening phase after application of thermal treatments of natural or artificial ageing is represented by the precipitations formed, which the more numerous and more evenly distributed in the mass of the basic solid solution, the higher the mechanical resistance of the $\mathrm{Al}-\mathrm{Zn}-\mathrm{Mg}-\mathrm{Cu}$ alloys. If ageing at higher temperatures and longer maintenance times continues, a decrease in mechanical properties is observed due to the increase in precipitate size by coagulation [5].

The alloys are put into service in the aeronautical industry at multidirectional stresses, therefore they must present an optimal combination of mechanical strength, plasticity, tenacity, fatigue strength, and good corrosion resistance.

In order to achieve this, it is necessary to replace the rough grain structure obtained from the alloy casting process as well as to modify the fibrous structure of the laminated semi-finished products, these being decisive factors in achieving optimal properties [6]. 
In order to achieve this objective, the properties of these alloys of different chemical compositions have been varied as a result of applying experimental variants of thermic and thermomechanical treatment.

In this paper the experimental researches and their results are rendered following the application of a thermal treatment of natural ageing with the aim of obtaining semi-finished products with a structure that will give the material the desired properties.

\section{Experimental research}

Experiments were performed on samples from the alloy with the chemical composition given in Table 1. The mechanical properties of the alloys studied according to EN 485-2-2007 [180] are presented in Table 2.

Table 1. Chemical composition of alloys under investigation

\begin{tabular}{|c|c|c|c|c|c|c|c|c|}
\hline Alloy & $\mathrm{Zn}$ & $\mathrm{Mg}$ & $\mathrm{Cu}$ & $\mathrm{Si}$ & $\mathrm{Fe}$ & $\mathrm{Cr}$ & $\mathrm{Mn}$ & $\mathrm{Al}$ \\
\hline AlZn4,5Mg1 & 4.5 & 1.4 & $\mathbf{0 . 5}$ & $\mathbf{0 . 3 5}$ & $\mathbf{0 . 4}$ & $\mathbf{0 . 3 5}$ & $\mathbf{0 . 2 5}$ & rest \\
\hline
\end{tabular}

Table 2. Alloy properties according to EN 485-2-2007 [7]

\begin{tabular}{|cc|c|c|c|c|}
\hline Mechanical property & $\begin{array}{c}\text { Rm, } \\
{[\mathrm{MPa}]}\end{array}$ & $\begin{array}{c}\text { Rp } 0,2 \\
{[\mathrm{MPa}]}\end{array}$ & $\begin{array}{c}\mathbf{A}_{5} \\
{[\%]}\end{array}$ & HB \\
\hline AlZn4,5Mg1 & $\mathbf{3 5 0}$ & $\mathbf{2 8 0}$ & $\mathbf{1 0}$ & $\mathbf{1 0 4}$ \\
\hline
\end{tabular}

These alloys were developed, cast into ingots and homogenized at S.C. ALRO S.A. Slatina. The test specimens for the mechanical tests were made according to the specifications given in SR EN 10 $002-1 / 1995$ [8] for the traction tests.
The alloy subjected to the research is an aluminum alloy in which the main alloying element is zinc and, as shown in the Al-Zn equilibrium diagram in Figure 1, the zinc content of this alloy being $4.5 \%$ $\mathrm{Zn}$, it belongs to the category of alloys deformable and hardening by heat treatment.

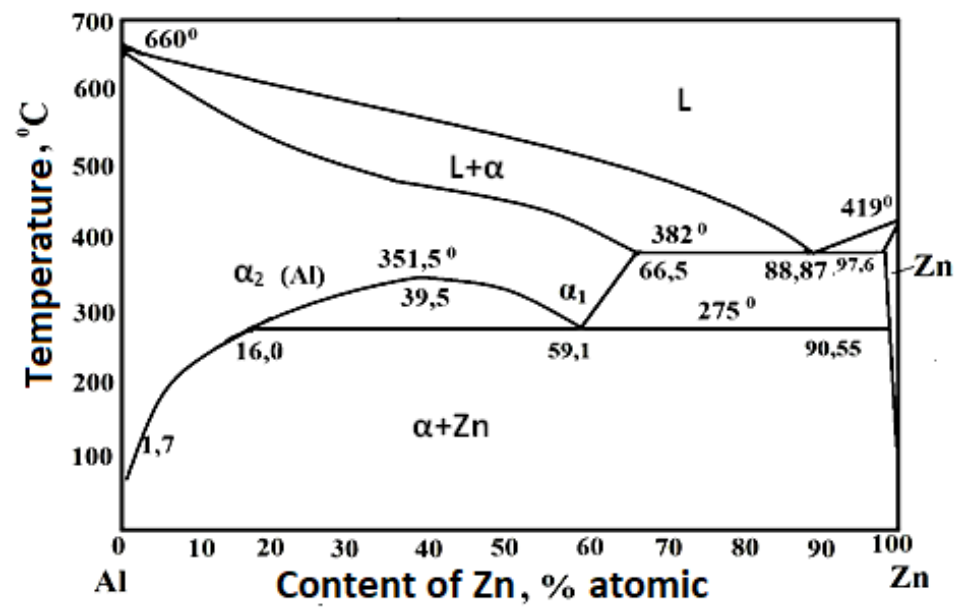

Fig. 1. Al-Zn balance diagram [9]

Based on the data presented in the literature on the thermal processing applied to the aluminum alloys, we have established the following technological variant of the alloy processing, which is illustrated schematically in Figure 2.

As a result of structural changes, homogenization improves the plasticity of alloys and uniformizes their final properties, reduces internal stresses and leads to changes in microstructure. In the first phase of homogenization, a part of $\mathrm{MgZn}_{2}$ is converted to $\mathrm{Al}_{2} \mathrm{CuMg}$, and the other untransformed part is dissolved in the mass of the solid solution. The AlFeSi-containing phase is partially converted to $\mathrm{Al}_{7} \mathrm{Cu}_{2} \mathrm{Fe}$.

The $\mathrm{Mg}_{2} \mathrm{Si}$ compound undergoes small changes, and slow cooling from the homogenization temperature to ambient temperature leads to precipitation of $\mathrm{MgZn}_{2}$ [3.9].

Hot lamination was achieved with only a $25 \%$ deformation because, due to the mechanical 
characteristics evaluated, the degree of deformation of $25 \%$ gave the most favorable combination between the hardness properties and the plasticity properties.

After hot rolling and cooling the material in air, the samples were heated in the oven at $500{ }^{\circ} \mathrm{C}$ and maintained at this temperature for 120 minutes in order to quench the solution.

Cooling from this temperature was done in water to affect the solution quenching in order to dissolve the alloying elements in aluminum, thus obtaining an over-saturated solid solution.
The higher the degree of deformation prior to the solution hardening process of the alloy, the finer the structure, and thus the secondary phases will dissolve at a higher rate at the quench temperature.

The range of quenching temperatures is very narrow for most aluminum alloys, but for the Al-Zn$\mathrm{Mg}-\mathrm{Cu}$ and $\mathrm{Al}-\mathrm{Zn}-\mathrm{Mg}$ alloys, the range of the solid solution is high and ranges between $400{ }^{\circ} \mathrm{C}$ and 580 ${ }^{\circ} \mathrm{C}[5,9,10-14]$.

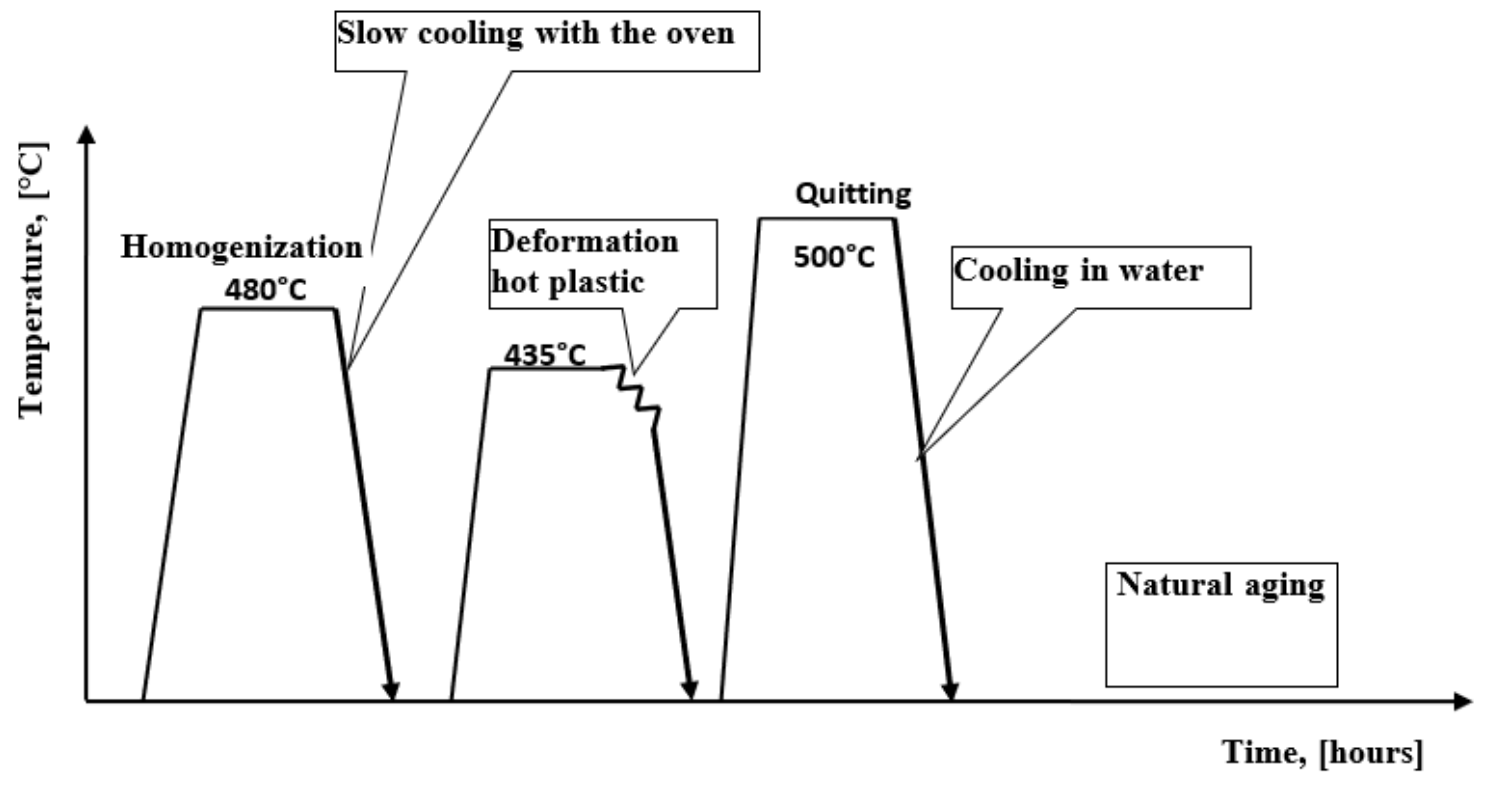

Fig. 2. Representation of the thermal processing scheme

The relationship between the solidus Ts temperature and the transformation curve temperature on the curve in $\mathrm{C}$, Tmin is linear: Tmin $=(0.7-0.9) \cdot$ Ts, [K], [5, 9, 11-14].

The structural hardening by precipitation from the supersaturated solid solution was achieved by the natural ageing of the material which had been left at ambient temperature in the laboratory for 60 days.

Measurement of property values was made after several time intervals: 24 hours, 72 hours, 168 hours, 360 hours, 720 hours, 1080 hours and 1440 hours.

Table 3. Properties of the alloy after natural ageing

\begin{tabular}{|c|c|c|c|c|}
\hline \multirow{2}{*}{ Aging time [hours] } & \multicolumn{4}{|c|}{ Mechanical characteristics } \\
\cline { 2 - 5 } & HB & $\begin{array}{c}\text { Rm } \\
\text { MPa }\end{array}$ & $\begin{array}{c}\text { Rpo, } \\
\text { MPa }\end{array}$ & $\begin{array}{c}\mathbf{A}_{\mathbf{0}} \\
\mathbf{\%}\end{array}$ \\
\hline 24 & 47 & 150 & 116 & 22 \\
\hline 72 & 56 & 179 & 138 & 19 \\
\hline 168 & 80 & 256 & 197 & 18 \\
\hline 360 & 111 & 355 & 273 & 17 \\
\hline 720 & 127 & 400 & 308 & 16 \\
\hline 1080 & 136 & 435 & 335 & 15 \\
\hline 1440 & 140 & 421 & 323 & 16 \\
\hline
\end{tabular}


Table 3 shows the values representing the arithmetic mean of 5 measurements after performing the tests for finding the values of the investigated properties. Mechanical strength properties increase as the natural aging time increases, with a peak for ageing time of 1,080 hours, and then decreases over 1440 hours.

The graphical representation of the mechanical properties variation with the natural ageing time of the samples that have undergone research on this topic is shown in Figures 3-6.

Ageing of the hardened alloys leads to the decomposition of the supersaturated solid solution with the appearance of the secondary phases in a controlled dispersion and the equilibrium approximation of the solid solution. The type, size, distribution and amount of precipitated particles in an alloy depend on temperature, ageing time and initial state of the microstructure.

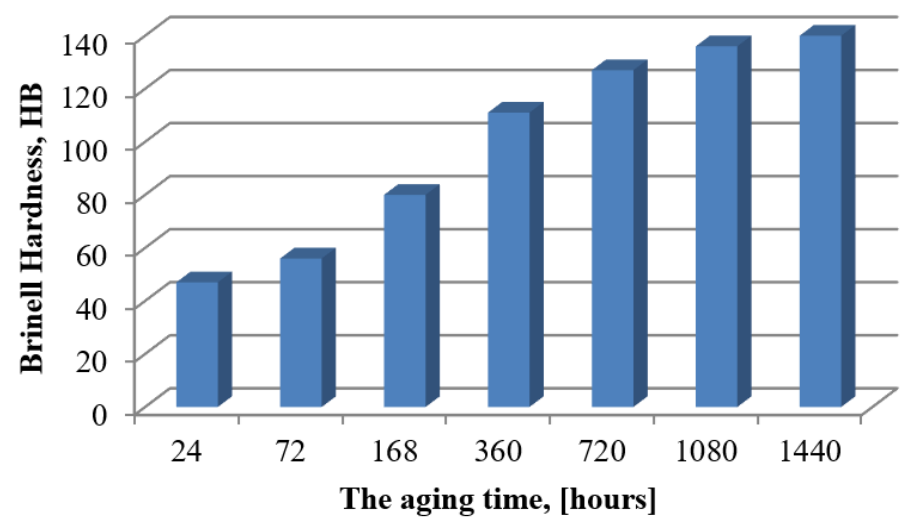

Fig. 3. Variation of Brinell hardness with aging

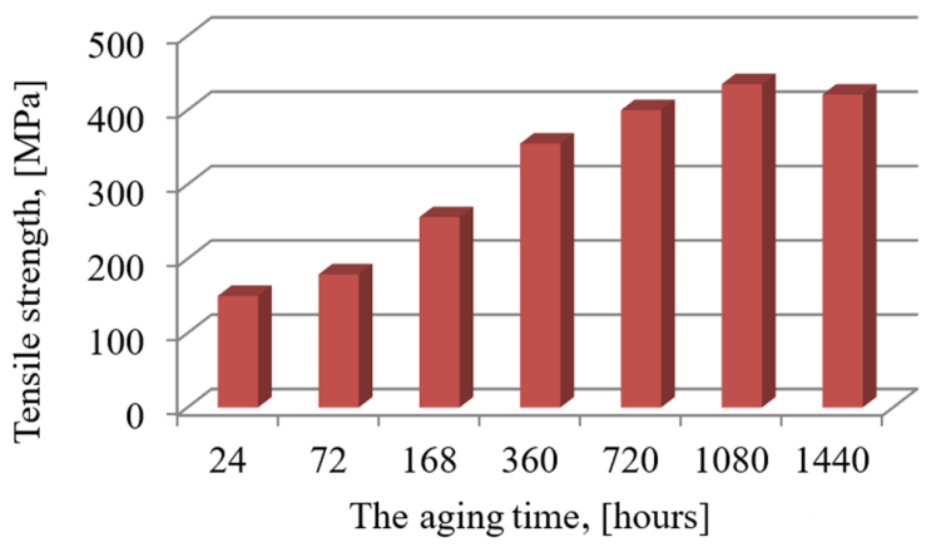

Fig. 4. Variation of mechanical strength at breaking with aging

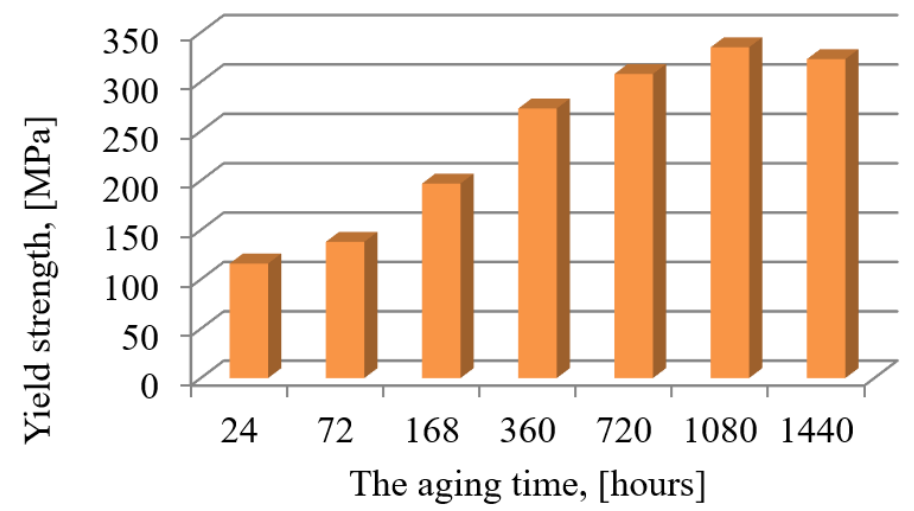

Fig. 5. Variation of flow limit with the aging time 


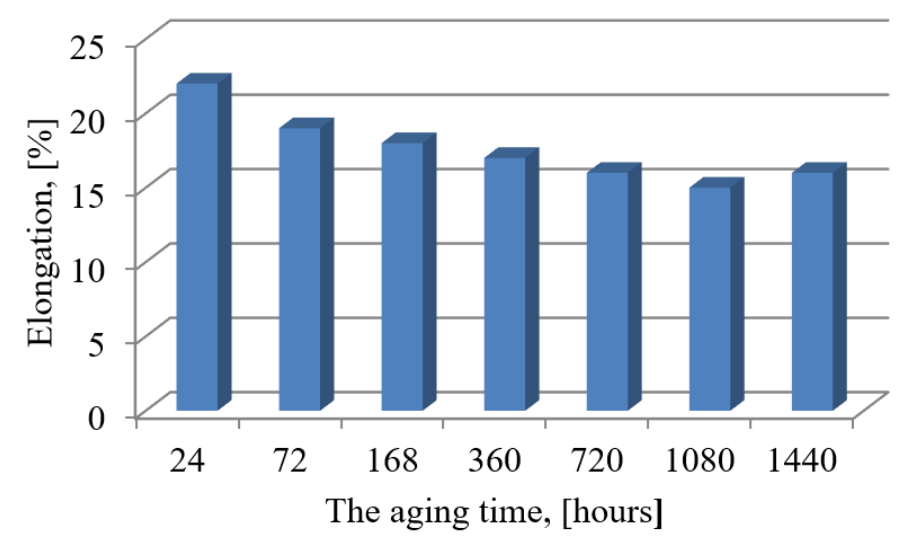

Fig. 6. Variation of elongation at break with aging

As it can be seen from the variation graphs of mechanical resistance, yield strength and Brinell hardness with ageing time, the two mechanical properties do not fall within the required norms for all these ageing times.

The decrease of the values of the mechanical resistance properties studied after natural ageing with the time of 1440 hours compared to those of the aging time of 1080 hours, is due to the occurrence of the coalescence phenomenon of the precipitates which has the effect of diminishing these values.

Elongation at break has the lowest value for samples left to naturally age for 1080 hours, after which, for naturally aged samples for 1440 hours, there is a slight increase but it is an increase in A5.

The increase of precipitations by the phenomenon of coalescence is responsible for this situation and in structural terms there is a decrease of the grain boundaries, which leads to the decrease of the mechanical properties of resistance, to the detriment of the plasticity.

\section{Conclusions}

After the research, the following conclusions can be drawn:

- for mechanical resistance, the values that fall within the limits prescribed by the Eeuronorm in force are those obtained when the ageing time was $360,720,1080,1440$ hours.

- for the flow limit, we obtained values that correspond to the Euronorm recommendations for the following natural ageing times: 720, 1080, 1440 hours.

- the values obtained for the Brinell hardness are above those prescribed by the Euronorm when natural aging lasts between 360 and 1440 hours.

- elongation at break decreases as the ageing time increases (Figure 3).
The graph in Figure 6 shows that the elongation records a minimum of 1080 hours, followed by a slight increase. For both resistance and elongation properties, this variation is explained by the fact that the precipitations formed during the natural ageing process have reached a critical value of their size, followed by their growth through coalescence. More precisely, there is the increase of the big ones on the account of the small ones and structurally, there is a decrease of the grain boundaries, which leads to the decrease of the mechanical properties of resistance, to the detriment of the plasticity properties.

\section{References}

[1]. Bane M., ş.a., Analiza structurii materialelor metalice, Editura Tehnică, Bucureşti, 1991.

[2]. Baker K. B., Rowe H. J., Aluminium, vol. III, Fabrication and Finishing, ASM, Ohio, 1994.

[3]. Cieśla M., Aluminium supplier selection for the automotive parts manufacturer, Metalurgija, 55, 2, p. 237-240, 2016.

[4]. Rometsch P. A., Zhang Y., Knight S., Transactions of Nonferrous Metals Society of China, 24, p. 2003-2017, 2014.

[5]. Bunea D., Şaban R., Vasile T., Gheorghe D., Brânzei M., Alegerea si tratamentele termice ale materialelor metalice, Editura Didactică şi Pedagogică. Bucureşti, 1996.

[6]. Chira I., Mărginean Şt., Metale şi aliaje neferoase turnate, Editura "Fundaţia Metalurgia Română", București, 2003.

[7]. ***, www.en-standard.eu/csn-en-573-3-2013aluminium.

[8]. ***, SR.EN. 10002-1/1995 - Incercarea la tracţiune.

[9]. Ienciu M., Moldovan P. et al., Elaborarea şi turnarea aliajelor neferoase speciale, Ed. Didactică şi Pedagogică, București, 1985.

[10]. Chira I., Cernat C., Tehnologia elaborării şi turnării aliajelor neferoase, Editura Litografia, București, 1988.

[11]. Dumitrescu C., Şaban R., Metalurgie fizică - Tratamente termice, Editura. Fair Partners, Bucuresti, 2001.

[12]. Piątkowski J., AlSi17Cu5Mg-Alloy as future material for castings of pistons for internal combustion engines, METABK 54(3), p. 511-514, 2015.

[13]. Armăşoiu P., Dobrotă D., Petrescu V., Analysis of metal lographic structure and hardness of aluminum alloy 3159 from the structure of vulcanization equipment, METABK 54(3), p. 547-550, 2015.

[14]. Essari A., Sariuglo F., Petrovic Z., Sedmak A., Samardžić I., Effect of aging on mechanical properties of Al-8Si-8Fe1.4V/SICP composites, METABK 55(2), p. 189-192, 2016. 